\title{
Retention and Turnover of Teaching Fraternity in Educational Sector with Special Reference to Degree Colleges in Bangalore
}

\author{
Haritha M, E A Parameshwar Gupta
}

\begin{abstract}
The study aims the intension of understanding the employee turnover and their retention strategies that can be practised. There exists a highExcellence education imparted in Indian educational institutions but at present there is a shortage of excellence teaching fraternity, which is a predicament situation. Hence the turnover rate is high in education sector and the functioning of the teaching fraternitydiffers from other professions. This study will show the comparison of the turnover and retention issues. This research is conducted in a degree educational institution in Bangalore on teaching fraternity by using qualitative method of data collection. The qualitative research methodology would be used to gather data from the Respondents. Responses will be collected with open-ended questionnaires as well structured interviews will be conducted to gain knowledge about turnover issues..
\end{abstract}

Index Terms: About four key words or phrases in alphabetical order, separated by commas.

\section{INTRODUCTION}

The high Turnover of teaching fraternity in educational institutions is unhealthy for the smooth running of institution since it impacts the growth and student progression. But some teaching fraternity leave and being replaced as expected in the education field. Teaching fraternity are the backbone of any educational institution. They should be protected properly in the interest of institution in an ambience which widens the employee commitment, and contributes to the growth of the institution. Teaching fraternity in an educational institution are the reasons for any success and therefore they need to be motivated and maintained in organisation at any cost to ensure the organisation to be locally, nationally and globally competitive in Retention managements of providing best rated qualitative education to the students. Turnover in an education institution becomes common only because of bad management strategy towards the teaching community. Many educational institutions finds it difficult to retain the qualitative workforce and heavy turnover can significantly impact the educational institutions performance and

Revised Manuscript Received on July 08, 2019.

Haritha M, PG Coordinator, Soundarya Institute of Management and Science, Bangalore.

Dr. E A Parameshwar Gupta, HOD- Department of M.Com, Kongadiyappa College, Bangalore.
Retention management. The demand for good teaching fraternity is day by day increasing and some reputed institutions provide better pay, infrastructure facilities and keep the morale of teachers at an higher rate.

\section{OBJECTIVES OF THE STUDY}

1. To study demographic profile of teacher respondents

2. To analyse the main reasons of employee turnover

3. To understand the motivating factors for retaining the Teaching fraternity in the same institution.

4. How do the perceptions of the top management and the

Teachingfraternity differ in regard to turnover?.

\section{STATEMENT OF THE PROBLEM}

The success or failure of the organisation depends on the quality of employees which commonly applicable for educational institution also. The employees of educational institutions would lead the organisation towards success and nurturing the young minds to create better society. The students success will go hand in hand with the effective teachers and ongoing interactions. In this context the employee turnover in educational institutions would be more important than manufacturing organisations. Because employee turnover in corporate lead to loss in income whereas the employee turnover in education could affect economically as well as future skills of the country.

\section{REVIEW OF LITERATURE}

While listing the main factor leading to employee turnover, we can see that recognition; career advancement, training and development, conflicts with top management, decision making power and talent management are the major factors, which were also found in the India Employee Retention Survey Research Report (Yiu \& Saner, 2008).

ARetention management, Strong (2011) states that the prospects of getting higher pay elsewhere is one of the most obvious driver of turnover. Further, the researcher reveals that this practice can be noticed at all level of economic ladder from executives and generously paid professionals in high stress positions to entry level workers.

Ng'ethe, J. et al. (2012) statesthat the employee retention refers to policies followed by the institutions that help to prevent valuable employees from leaving their present job. The 
authors reveals that hiring knowledgeable people for the job is essential for an employer and retention of employees in professional colleges which includes Engineering, Architecture, Management, Medical etc., is a serious concern.

Abdul et al. (2014) reported that pay more to the employees than the compensation to solve the problem of turnover.

\section{NEED AND SCOPE OF THE STUDY}

The proposed study focuses on turnover and retention of teachingfraternity and since turnover is a global phenomenon, various issues are being focused upon by the study. Teaching fraternityis affected by different aspects that not only affect the teaching fraternity but also top level management. Organization is being helped by this research in order to analyse the need for change in the process that would result in not only retaining the teaching fraternity but also attracting them. Since there are many reasons associated with turnover, the main causes of turnover of the teachingfraternity in an educational sector will be analysed along with the reasons and how the management can take steps to prevent such outcomes in the future. The study would also realize the causes and effects of high turnover rates and at the end provides certain recommendations that would help in creation of effective retention strategies in the Indian education system with special reference to Bangalore context

\section{RESEARCH METHODOLOGY}

This chapter concentrates on explaining the researcher plan of research. The study focuses on identifying the reasons behind high attrition rate in degree educational institutions in Bangalore. The study has made attempt to find the reasons for attrition rate from employee perspective and findings could vary based on sample difference and timing of the research.

\section{Collection of Data}

The data has been collected using structured questionnaire and self monitored to enhance the effectiveness of the research.

Sample size: The sample has been chosen based on convenience sampling and selected 60 respondents for the study purpose due to time constraint.

\section{Sources of Data}

Primary Source: The data has been collected from the degree college's faculty members at Bangalore area.

Secondary sources: The secondary data has been collected through various websites, books and published articles.

Plan of Analysis:The data has been analysed using tabular method.

\section{Limitations}

The study will have many limitations. Firstly, the study conducted in Bangalore, which will make it difficult to cover all the colleges and will be time-consuming. Secondly, the small sample size might also act as a negative factor in analysing the data on turnover, as only few responses will be used in the findings. Thirdly, the research focuses only on particular educational institution, hence not giving an overview of the issue of turnover in the entire Indian education sector. Fourthly data, the research findings may not applicable uniquely to Indian education system due to area restriction.

\begin{tabular}{|c|c|c|}
\hline \multicolumn{3}{|c|}{$\begin{array}{l}\text { Analysis Of Findings and Interpretation } \\
\text { Q1:Gender }\end{array}$} \\
\hline $\begin{array}{l}\text { Particul } \\
\text { rs }\end{array}$ & $\begin{array}{ll}\text { No. } & \text { Of } \\
\text { Respondents } & \\
\end{array}$ & $\begin{array}{l}\text { Percent } \\
\text { age }\end{array}$ \\
\hline Male & 26 & 43.33 \\
\hline Female & 34 & 56.67 \\
\hline Total & 60 & 100 \\
\hline
\end{tabular}

The sample population was equally divided among both the genders and there was no particular gender which has dominated. This fact is shown by the fact that there were 26 male respondents which accounted for $43.33 \%$ of total valid sample population. On the other hand there were 34 female candidates which were $56.67 \%$ of total valid sample population. This shows that the data has been collected with no biasness and its analysis would not be based on any biasness.

Q2. Age

\begin{tabular}{|c|c|c|}
\hline Age group & $\begin{array}{cc}\text { No. } & \text { Of } \\
\text { Respondents } & \\
\end{array}$ & $\begin{array}{l}\text { Percent } \\
\text { age }\end{array}$ \\
\hline Below 25 & 4 & $7 \%$ \\
\hline $25-35$ & 14 & $23.33 \%$ \\
\hline $35-45$ & 28 & $46.67 \%$ \\
\hline $45-55$ & 12 & $20 \%$ \\
\hline $\begin{array}{c}55 \text { and } \\
\text { Above }\end{array}$ & 2 & $3 \%$ \\
\hline Total & 60 & 100 \\
\hline
\end{tabular}

It was found that out of total 60 valid respondents, $7 \%$ belonged to age group of less than 25 years old, which means they were newly employed. $23.33 \%$ respondents were among the age group of 25-35 years and there were $46.67 \%$ respondents that belonged to the age group of 35-45 years. In the age group of 45-55 years, there were $20 \%$ respondents. In the age group of $55 \&$ above, there were $3 \%$ respondents. This shows that there was 35 to 45 age group is more comparatively than other age group.

Q3: How long have been working in the same organisation?

\begin{tabular}{|l|c|c|}
\hline $\begin{array}{c}\text { Experience (No. Of } \\
\text { Years) }\end{array}$ & $\begin{array}{c}\text { No. } \\
\text { Respondents }\end{array}$ & $\begin{array}{c}\text { Percent } \\
\text { age }\end{array}$ \\
\hline $0-2$ & 23 & $38.33 \%$ \\
\hline $2-5$ & 18 & $30 \%$ \\
\hline $5-10$ & 12 & $20 \%$ \\
\hline $10-15$ & 4 & $7 \%$ \\
\hline 15 and Above & 3 & $4.67 \%$ \\
\hline Total & $\mathbf{6 0}$ & $\mathbf{1 0 0}$ \\
\hline
\end{tabular}

It was found that there were newly recruited people along with people having 15 years 
and above of experience. In the research, there were $38.33 \%$ respondents that were having experience less than 2 years. On the other hand, there were $4.67 \%$ people which had experience of more than 15 years also. Talking about the people having experience of 2-5 years in education sector in India, there were $30 \%$ respondents that belonged to the same category. In the category of 5-10 years of experience, there were $20 \%$ respondents. However there were $7 \%$ respondents that had experience more than 10 years but less than 15 years. This shows that the responses were gathered from people with all sorts of experiences.

Q4: Reasons that will cause you to consider for turnover from the institution?

\begin{tabular}{|c|c|c|}
\hline $\begin{array}{c}\text { Reason for } \\
\text { Turnover }\end{array}$ & $\begin{array}{c}\text { No. } \\
\text { Respondents }\end{array}$ & $\begin{array}{c}\text { Percent } \\
\text { age }\end{array}$ \\
\hline $\begin{array}{c}\text { Insufficient Payment } \\
\text { Lack of career } \\
\text { advancement }\end{array}$ & 24 & $40 \%$ \\
\hline Work Load & 6 & $16.67 \%$ \\
\hline Working conditions & 12 & $10 \%$ \\
\hline Extra Benefits job & 5 & $20 \%$ \\
\hline $\begin{array}{l}\text { Alternative } \\
\text { opportunities }\end{array}$ & 3 & $8.33 \%$ \\
\hline Others & $\mathbf{6 0}$ & $0 \%$ \\
\hline Total & $\mathbf{1 0 0}$ \\
\hline
\end{tabular}

Major respondents mentioned the insufficient payment was the reason for leaving the job according to $40 \%$ of the respondents. Second major reason was working condition as per $20 \%$, Along with that $16.67 \%$ others went for the reason i.e. lack of career advancement as an important factor for leaving the organization. In the last spot there were three reasons that were chosen by respondents. These were,workload (10\%), Extra benefits (8.33\%) and Alternative job opportunities $(5 \%)$ and other reasons were nil as per the respondents. Knowing all the striking factors would help the researcher to recommend sound retention policies based on these factors.

Q5: What are your reasons for staying with this organisation? (Any three)

\begin{tabular}{|c|c|c|c|}
\hline $\begin{array}{c}\text { Pay } \\
\text { system }\end{array}$ & $\begin{array}{c}\text { Flexible } \\
\text { working } \\
\text { hours }\end{array}$ & $\begin{array}{c}\text { Career } \\
\text { development }\end{array}$ & $\begin{array}{l}\text { Leadershi } \\
\mathbf{p} \\
\text { Managemen } \\
\mathbf{t}\end{array}$ \\
\hline $\begin{array}{c}\text { Holida } \\
\text { ys/ } \\
\text { Vacancy }\end{array}$ & $\begin{array}{c}\text { Work-life } \\
\text { balance }\end{array}$ & Training & $\begin{array}{c}\text { Annual } \\
\text { bonus }\end{array}$ \\
\hline $\begin{array}{c}\text { Job } \\
\text { profile }\end{array}$ & $\begin{array}{c}\text { Talent } \\
\text { Management }\end{array}$ & & \\
\hline
\end{tabular}

\begin{tabular}{|c|c|c|}
\hline Options & $\begin{array}{c}\text { No. } \\
\text { Respondents }\end{array}$ & $\begin{array}{c}\text { Percent } \\
\text { age }\end{array}$ \\
\hline $\begin{array}{c}\text { Option } \\
1(\mathrm{~A}, \mathrm{~B} \& \mathrm{C})\end{array}$ & 26 & $43 \%$ \\
\hline
\end{tabular}

\begin{tabular}{|l|c|c|}
\hline $\begin{array}{l}\text { Option 2 (A,F } \\
\& \mathrm{G})\end{array}$ & 24 & $40 \%$ \\
\hline $\begin{array}{l}\text { Option 3 (B,J \& } \\
\text { I) }\end{array}$ & 5 & $8.3 \%$ \\
\hline $\begin{array}{l}\text { Option 4 (C,G \& } \\
\text { H) }\end{array}$ & 5 & $8.7 \%$ \\
\hline Total & $\mathbf{6 0}$ & $\mathbf{1 0 0}$ \\
\hline
\end{tabular}

The options were categorised based on the opinion provided for the purpose of analysis and most number of respondents i.e. $43 \%$ were of the opinion that pay system, flexible hours and career development is the factor they are staying. There were $40 \%$ of respondents that considered pay system, work life balance and training as an important factor while the other two options i.e. flexible working hours, leadership management, job profile, career development, training and annual bonus as equal factors for retaining in the same organisation.

Q6: Management is really interested in motivating the teaching fraternity?

\begin{tabular}{|l|c|c|}
\hline Opinions & $\begin{array}{c}\text { No. } \\
\text { Respondents }\end{array}$ & $\begin{array}{c}\text { Percent } \\
\text { age }\end{array}$ \\
\hline Strongly Agree & 8 & $13.33 \%$ \\
\hline Agree & 17 & $28.33 \%$ \\
\hline Neutral & 24 & $40 \%$ \\
\hline Disagree & 6 & $10 \%$ \\
\hline $\begin{array}{c}\text { Strongly } \\
\text { Disagree }\end{array}$ & 5 & $8.34 \%$ \\
\hline Total & $\mathbf{6 0}$ & $\mathbf{1 0 0}$ \\
\hline
\end{tabular}

It was found that major of the valid sample population i.e. $40 \%$ of respondents neutral with this fact. There were $28.33 \%$ respondents who agree to fact that their management actively motivates their Teaching fraternity. $13.33 \%$ respondents out of this total were those were strongly agreed for the statement. There were $10 \%$ respondents that disagreed to the fact of their management doing something to motivate them. There was $8.34 \%$ respondent felt that strongly disagreed to the fact their management lays any emphasis on motivating teaching fraternity.

Q7: My expectations have been met after I joined the organisation?

\begin{tabular}{|c|c|c|}
\hline Opinions & $\begin{array}{cc}\text { No. } & \text { Of } \\
\text { Respondents }\end{array}$ & $\begin{array}{l}\text { Percent } \\
\text { age }\end{array}$ \\
\hline Strongly Agree & 12 & $20 \%$ \\
\hline Agree & 26 & $43.33 \%$ \\
\hline Neutral & 12 & $20 \%$ \\
\hline Disagree & 10 & $16.67 \%$ \\
\hline $\begin{array}{l}\text { Strongly } \\
\text { Disagree }\end{array}$ & 0 & 0 \\
\hline Total & 60 & 100 \\
\hline
\end{tabular}

It was found that $43.33 \%$ respondents agreeing to the 
Retention and turnover of teaching fraternity in Educational sector with special reference to degree colleges in Bangalore

meeting of their expectations and $20 \%$ person had agreed strongly. $20 \%$ respondentshad gone towards being neutral towards meeting their expectations. However, there were $16.57 \%$ respondents that disagreed to the fact that their expectations have been met after joining the organization. $0 \%$ respondents strongly disagreed to the same fact.

Q8: The working condition is satisfactory for the teaching fraternity in your organisation?

\begin{tabular}{|l|c|c|}
\hline Opinions & $\begin{array}{c}\text { No. } \\
\text { Respondents }\end{array}$ & $\begin{array}{c}\text { Percent } \\
\text { age }\end{array}$ \\
\hline Strongly Agree & 14 & $23.33 \%$ \\
\hline Agree & 26 & $43.33 \%$ \\
\hline Neutral & 16 & $26.67 \%$ \\
\hline Disagree & 4 & $6.67 \%$ \\
\hline $\begin{array}{c}\text { Strongly } \\
\text { Disagree }\end{array}$ & 0 & 0 \\
\hline Total & $\mathbf{6 0}$ & $\mathbf{1 0 0}$ \\
\hline
\end{tabular}

Major respondent's i.e. $66.66 \%$ respondents felt that the working conditions in their organization being satisfactory. However, there were $26.67 \%$ respondents those are neutral in this regard. On the other hand it was found that $6.67 \%$ of the sample population were not satisfied with the working conditions of their respective organizations.

Q9: How often have you been involved in training and development activity in you work place?

\begin{tabular}{|c|c|c|}
\hline $\begin{array}{l}\text { Freque } \\
\text { ncy }\end{array}$ & $\begin{array}{cc}\text { No. } & \text { Of } \\
\text { Respondents } & \end{array}$ & $\begin{array}{l}\text { Percent } \\
\text { age }\end{array}$ \\
\hline Weekly & 2 & $3.33 \%$ \\
\hline Monthly & 6 & $10 \%$ \\
\hline $\begin{array}{l}\text { Quarterl } \\
\mathrm{y}\end{array}$ & 38 & $63.33 \%$ \\
\hline Yearly & 14 & $23.34 \%$ \\
\hline Total & 60 & 100 \\
\hline
\end{tabular}

It was found that majority of responses i.e. $63.33 \%$ were involved in quarterly training and development. This means that in every three months, the teaching fraternity were given training and development. $23.34 \%$ responses went through yearly training and development and $10 \%$ respondents found them involved in monthly training and development. However, there were only $3.33 \%$ respondents that were engaged in weekly training and development programme. Continuous training and development ensures continuous updation among teaching fraternity.

Q10: Choose the factors on which the management can improve?

\begin{tabular}{|l|c|c|}
\hline Factors & $\begin{array}{c}\text { No. } \\
\text { Respondents }\end{array}$ & $\begin{array}{c}\text { Percent } \\
\text { age }\end{array}$ \\
\hline High Pay Scale & 20 & $33.33 \%$ \\
\hline Career Growth & 18 & $30 \%$ \\
\hline Flexible Working & 10 & $16.67 \%$ \\
\hline
\end{tabular}

\begin{tabular}{|l|l|l|}
\hline Hours & & \\
\hline Job Security & 12 & $20 \%$ \\
\hline Total & $\mathbf{6 0}$ & $\mathbf{1 0 0}$ \\
\hline
\end{tabular}

The above table shows that highest respondents have felt that high pay scale could be resolving measure to turnover, $30 \%$ of respondents expressed that career growth assurance could reduce the turnover. However $20 \%$ of respondents feels providing job security and $16.67 \%$ respondents voted for flexible working hours as an effective tool to reduce turnover.

Q11. What do you think the management can do to reduce stress levels for the teaching fraternity?

\begin{tabular}{|c|c|c|}
\hline Measures & $\begin{array}{c}\text { No. } \\
\text { Respondents }\end{array}$ & $\begin{array}{c}\text { Percent } \\
\text { age }\end{array}$ \\
\hline High Pay Scale & 2 & $3.33 \%$ \\
\hline $\begin{array}{c}\text { Employee } \\
\text { Motivation }\end{array}$ & 12 & $20 \%$ \\
\hline $\begin{array}{c}\text { Effective } \\
\text { Leadership }\end{array}$ & 15 & $25 \%$ \\
\hline Work Life Balance & 28 & $46.67 \%$ \\
\hline Benefits & 3 & $5 \%$ \\
\hline Total & $\mathbf{6 0}$ & $\mathbf{1 0 0}$ \\
\hline
\end{tabular}

It was found that $46.67 \%$ of respondents expressed that following work life balance could reduce the stress among teaching fraternity. There were $25 \%$ others that considered effective leadership as an important factor for reduction of stress. Employee motivationwas chosen by $20 \%$ respondents. The remaining factors i.e. high pay scale and benefits were chosen by $5 \%$ and $3.33 \%$ respondent each. The reason behind asking this question was to know the factor that affects employee stress in education institutions.

\section{Suggestions}

The organization should identify the crucial talent initiative to attract and retain the employee. They should know which talent management elements can have the greatest impact on the business and therefore provide a better basis for prioritization and implementation.

$>$ To create a sophisticated talent management enviro nment, organizations must:

$>$ Define a clear vision for talent management.

$>$ Develop a roadmap for technology and process integration.

$>$ Integrate and optimize processes.

Apply robust technology to enable processes.

$>$ Prepare the workforce for changes associated with the new environment.

\section{CONCLUSION}

However Talent management processes must create a comprehensive profile of their talent. They must be able to track meaningful talent related 
information Retention Management about all of their people

- Teaching fratarnity, contractors, or candidates.

And The working culture of the organization should be improved and maintained to retain talent in long run.

More certified training should be given to the employee to boost their effectiveness and efficiency. It should be used as a tool of motivation. The organizations should have prefixed criteria to define the skills set a person must have in order to be declared as a highly skilled employee. Also, in this particular industry sector, the systems should be competitive enough. But in order to retain the Teaching fraternity, only developing a good system will not help, but the Institution have to do much more than that.

\section{REFERENCES}

1. Confederation of Indian Industry, 2008. India Employee Turnover Study Research Report. Indian: Centre for Socio-Eco-Nomic Development.

2. Ed. Shubha Tiwari (2005). Education in India. India: Atlantic Publishers \& Dist. p200-250.

3. William J. Wasmuth and Stanley W. Davis,. (1983). Managing employee turnover. Cornell Hotel and Restaurant administration quarterly. 1 (1), $15-20$.

4. Gretchen Rhines Cheney, Betsy Brown Ruzzi and Karthik Muralidharan. (November 2005). A Profile of the Indian Education System. National Center on Education and the Economy. 1 (1), 1-29.

5. Rashmi ShaRetention managementa. (Feb 2, 2012). Teachers on the Move: International Migration of School Teachers From India. Journal of Studies in International Education. 1 (1), 1-23.

6. James M. Vardaman, David G. Allen, Robert W. Renn and Karen R. Moffitt. (Oct 10, 2008). Should I stay or should I go? The role of risk in employee turnover decisions. Human Relations. 61 (11), 1-34.

7. Henry Ongori. (22, May 2007). A review of the literature on employee turnover. African Journal of Business Management . 1 (1), 01-06.

8. Pawan S. Budhwar, Arup VaRetention managementa, Neeru Malhotra, Avinandan Mukherjee, (2009) "Insights into the Indian call centre industry: can internal marketing help tackle high employee turnover?", Journal of Services Marketing, Vol. 23 Iss: 5, pp.351 - 362

9. Zheng WeiBo1*, Sharan Kaur2 and Tao Zhi3. (2010). A critical review of employee turnover model (1938-2009) and development in perspective of perfoRetention managementance. African Journal of Business Management. 4 (19), 1-13.

\section{AUTHORS PROFILE}

Haritha M PG Coordinator, Soundarya Institute of Management and Science, Bangalore.

Dr. E A Parameshwar Gupta HOD- Department of M.Com, Kongadiyappa College, Bangalore. 